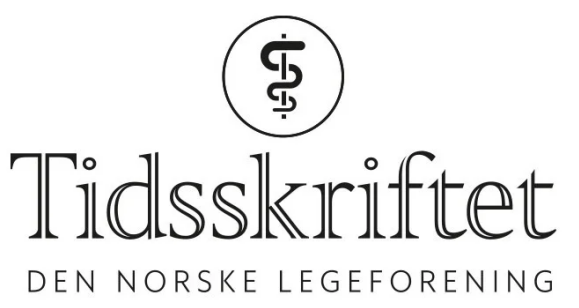

\title{
Metabolismen varierer mye med alder
}

FRA ANDRE TIDSSKRIFTER

HAAKON B. BENESTAD

Universitetet i Oslo

Variasjonene kan ha klinisk betydning.

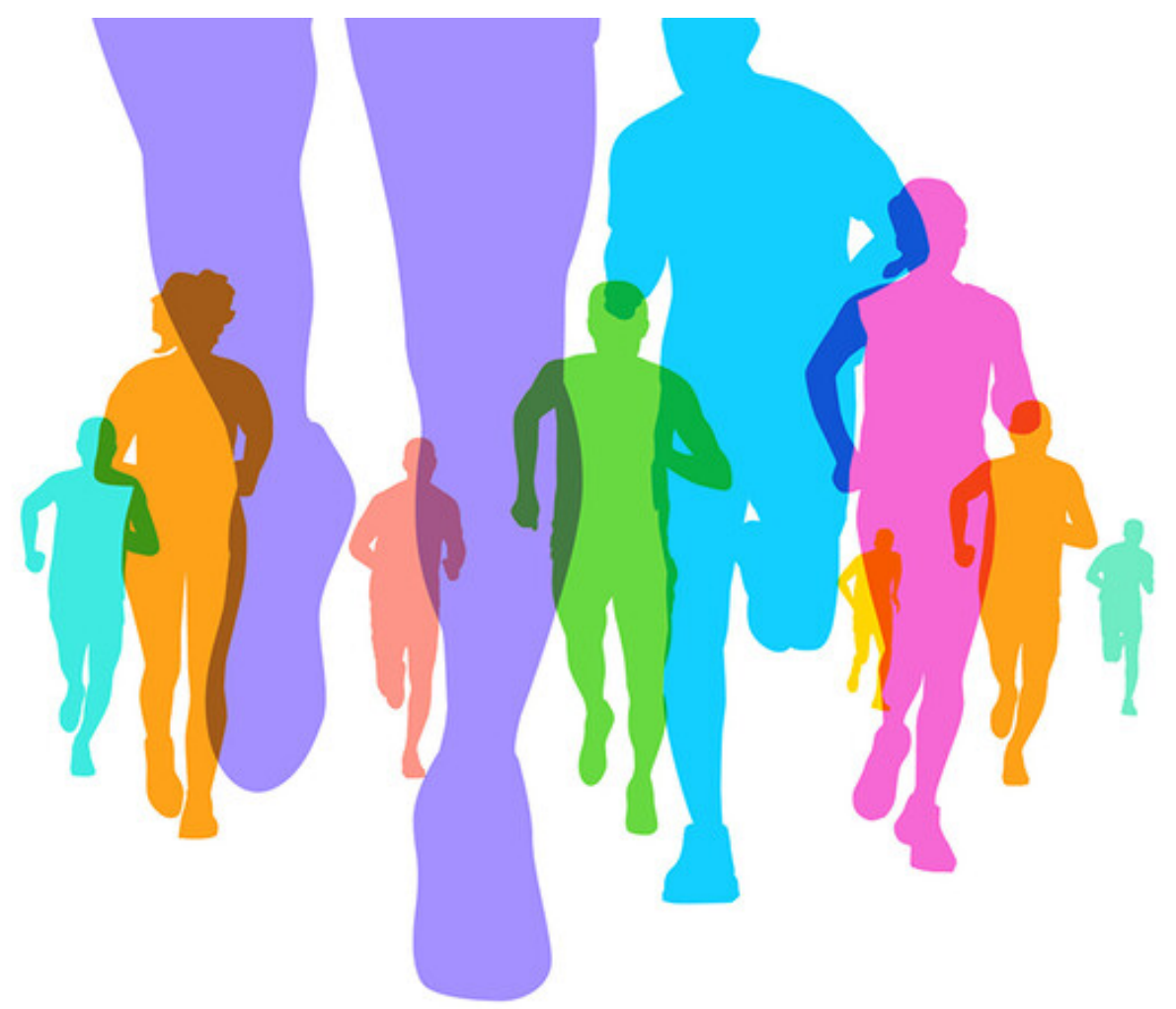

Illustrasjon: smartboy10/iStock

Næringsstoffene våre avgir ved skrittvis katabolisme energi som kan brukes i kjemiske reaksjoner, mest i form av ATP eller som varme. For det meste ender næringsstoffene som vann og karbondioksid. 
Totalmetabolismen er blitt målt direkte i kroppskalorimeter (ved varmeovergangen) eller indirekte ved oksygenforbruk (f.eks. ved kondisjonsmåling). Men gullstandarden ved metabolismemåling under vanlige, frie livsbetingelser er nå dobbeltmerket vann-metoden. Da inntas en viss mengde vann merket med tunge hydrogenatomer $\left({ }^{2} \mathrm{H}\right)$ og oksygenatomer $\left({ }^{18} \mathrm{O}\right)$. Forskjellen i utskillelse av de to isotopene gjør det mulig å beregne $\mathrm{CO}_{2}$-utskillelsen og dermed metabolismen, siden hydrogenisotopen bare utskilles i vann, mens oksygenisotopen utskilles både i vann og i karbondioksid.

Hvordan totalmetabolismen varierer gjennom livsløpet, er nå undersøkt i et gigantisk samarbeidsprosjekt som brukte dobbeltmerket vann-metoden (1). Over 6 40o personer i alderen fra 8 dager til 95 år fra 29 land, inkludert Norge, deltok i studien. Det mest interessante funnet var de normaliserte verdiene, det vil si tilpassede data uttrykte i megajoule per kilogram fettfri vevsmasse.

Forskerne delte livsløpet i fire faser. Nyfødte hadde i gjennomsnitt samme tilpassede verdier som voksne, men verdiene steg med omtrent 50 \% frem til ettårsalderen, for så gradvis å synke frem til ca. 20-årsalderen, og var deretter ganske konstante frem til ca. 6oårsalderen. Etter det så man et raskt fall - i denne aldersperioden øker insidensen av kroniske lidelser kraftig. Endringene i basalmetabolismen fulgte stort sett endringene i totalmetabolismen.

Det var ingen avvik i puberteten, heller ikke under graviditet. Menn hadde høyere absolutte verdier enn kvinner, men ikke tilpassede verdier for fettfri vev. Fysisk aktivitet, målt med akselerometer ved ulike aldre, passet godt med de tilpassede totalverdiene. Det var store individuelle variasjoner både i alder ved faseoverganger og i normaliserte verdier hos de ulike aldersgruppene.

- Enkelt sagt viser denne studien at barn ikke er små voksne, sier Bjørn S. Skålhegg, som er professor ved Avdeling for ernæringsvitenskap, Universitetet i Oslo.

- Barn skal ikke behandles som voksne, verken medisinsk eller på annen måte. Også personer eldre enn 60 år bør få alderstilpasset behandling, sier Skålhegg.

- Energiforbruket var forskjellig i hver av de fire aldersgruppene, noe som viser behovet for individuell medisinsk behandling. Studier av personer med progeri, en sjelden genetisk sykdom som kjennetegnes av akselerert alderdom og økende insidens av kronisk sykdom, har blitt tatt til inntekt for at aldring er genetisk styrt. En fortsettelse av denne studien kan kanskje belyse andre mulige årsaker til aldring, blant annet visse livsstilsfaktorer, sier Skålhegg.

\section{LITTERATUR}

1. Pontzer H, Yamada Y, Sagayama H et al. Daily energy expenditure through the human life course. Science 2021; 373: 808-12. [PubMed][CrossRef]

Publisert: 11. oktober 2021. Tidsskr Nor Legeforen. DOI: 10.4045/tidsskr.21.0623

(C) Tidsskrift for Den norske legeforening 2023. Lastet ned fra tidsskriftet.no 26. april 2023. 